\title{
Synthesis of polymer-surfactants by gamma irradiation for removal nickel ions from aqueous solution
}

\author{
Mai M. Mamdouh ${ }^{a^{*}}$, Fatma H. abdel-salamb ${ }^{b}$ Nabila A. Maziad ${ }^{c}$ and Omyma A. M. Ali \\ ${ }^{a}$ Chemistry Department, Faculty of Women for Arts, Science and Education, Ain Shams University, Cairo, \\ Egypt.

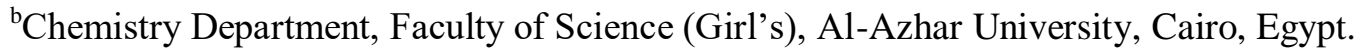 \\ 'Polymer Chemistry Department, National Center for Radiation Research and Technology Atomic Energy \\ Authority, Cairo, Egypt.
}

\begin{abstract}
Two amphoteric surfactants 2-((3-carboxyacryloxy)oxy)-3-(hexadecyloxy)-N,N,Ntrimethylpropane-1-ammonium chloride and N-(2-(carboxylatomethoxy)-3(hexadecyloxypropyl)dimethyl glycinate were synthesized and characterized by different techniques. Then, two polymer surfactants were prepared from the reaction of acrylic acid and acrylamide with two amphoteric surfactants by gamma irradiation. The functional and bond structure of these polymer surfactant compounds were established by FT-IR. The critical micelle concentration $(\mathrm{cmc})$ and surface tensions were measured and the values lie in the range 0.0005 $0.00141 \mathrm{~mol} \mathrm{~L}^{-1}$. The swelling of the two polymer surfactants was studied. The swelling percentages of the two surfactants are 1790 and $1492 \%$, respectively. The copolymers hydrogel were used in removal of heavy metal from waste water. The factors affecting the removal of heavy metal as contact time, initial concentration of metal ion, and temperature were investigated. It was found that the percentage of removal of nickel ion increases with increasing the time and temperature.
\end{abstract}

Keywords: Gamma irradiation; surfactants; polymers; swelling

\section{Introduction}

Water pollution with heavy metal ions is a serious problem due to their serious toxicity to human beings and other living organisms, heavy metals cause serious health effects, including cancer, organ damage, nervous system damage, and in extreme cases death [1-3]. Numerous research

*Corresponding author: Mai M. Mamdouh, Chemistry Department, Faculty of Women for Arts, Science and Education, Ain Shams University.

E-mail: Mai.mamdoh23@yahoo.com 
efforts are being done to develop methods to remove heavy metal ions. These techniques include filtration, chemical precipitation, neutralization, chelating ion- exchange and adsorption [4-9]. Among these techniques, adsorption is generally preferred for the removal of heavy metal ions due to its high efficiency, easy handling, availability of different adsorbents and cost effectiveness [1011]. In this paper we use adsorption method by using polymer surfactant interaction due to great interest in many applications such as drug delivery, inks, cosmetics, detergents, and other industrial purposes as waste water treatment [12-15]. Zwitterion surfactants which contain both positively and negatively charged are increasingly attracting the interest of researchers both an industrial application and within academic fields. This is due to their unique properties [16-19] such as excellent water solubility, broad isoelectric ranges, mildness to the skin and eyes, high foam stability in sensitivity to the presence of salts and to temperature, synergistic effect with a wide variety of ionic and nonionic surfactants and resistance to hard water and to degradation by oxidizing and reducing agents [20]. Betaines important zwitterion surfactants are widely used in cosmetic, pesticides, leather and have been proposed for enhanced oil recovery. In order to demonstrate our recovery, two betaines are synthesized. The surface activity of the two prepared surfactants at $25^{\circ} \mathrm{C}$ is evaluated. Hydrogels are three dimensionally dense cross-linked polymer network structures composed of functional hydrophilic groups which have the ability to absorb significant amount of water and solute molecules. The ability to absorption of hydrogel is dependent on the presence of hydrophilic functional groups such as $\mathrm{OH}, \mathrm{COOH}$ which make hydrogel hydrophilic [21-22]. The presence of functional groups and the nature of cross-linking agents are important parameters that control the swelling ability of the hydrogel [23-24].Hydrogel has a porous structure and many hydrophilic groups, which can be used for heavy-metal ion removal [25]. Many researchers concentrated on the metal ion recovery using polymers because they are usable, easy handing and have higher adsorption capacities, efficiencies as well as high selectivity to some metal ions. Thus, the present aim of the work is to studied the application of the prepared polymer-surfactant compounds to remove heavy metals especially $\mathrm{Ni}^{+2}$ from waste water. 


\section{Experimental}

\subsection{Materials and methods}

Acrylic acid (AAc) and acrylamide (AAm) were purchased from Merck Germany Company with purity 99\%. All used chemicals were used without further purification. The FTIR measurements (KBr pellets) were recorded using a Perkin-Elmer spectrophotometer model 1430, in the range of 400-4000 $\mathrm{cm}^{-1} .{ }^{1} \mathrm{H}$ NMR spectra were performed on Brucker500 $\mathrm{MHz}$ spectrometer using $\mathrm{CDCl}_{3}$ with TMS as internal standard. Elemental analysis was carried out using Perkin-Elmer elemental analyzer.

\subsection{Synthesis of 1-chloro-3-(hexadecyloxy)propane-2OL (1)}

This compound was prepared according to the method described elsewhere in detail [24].

\subsection{Synthesis of 2-((3-carboxyacryloxy)oxy)3-(hexadecyloxy)-1-propyl chloride (2)}

1-chloro-3-(hexadecyloxy)propane-2OL (1) (0.11 mol) was loaded into a two neck flask and heated to $60-70^{\circ} \mathrm{C}$. The temperature was kept to be constant at this level and maleic anhydride $(0.12 \mathrm{~mol})$ was continuously added by stirring and temperature was kept on a constant level. The heat of the reaction caused the anhydride to melt. The temperature was raised to $120-130{ }^{\circ} \mathrm{C}$ in presence of P-toulene sulfonic acid and benzene as solvent. The water removed from the mixture was collected using Dean-Staru apparatus and the completion of the reaction was achieved by measuring the volume of the collected water which equal to the theoretical volume of the reaction. The crude product was purified by crystallization with petroleum ether/ethanol $(30: 50 \mathrm{v} / \mathrm{v})$ several times and the purified ester was dried [24].

\subsection{Synthesis of 2-((3-carboxyacryloxy)oxy)-3-(hexadecyloxy)-N,N,N-trimethylpropane-1- ammonium chloride ( 3 )}

2-((3-carboxyacryloxy)oxy)3-(hexadecyloxy)-1-propyl chloride (2) (0.01 mol) was added to 0.01 mol of sodium bicarbonate and the reaction mixture was stirred for $30 \mathrm{~min}$. Using acetone as solvent. The reaction was carried out below $20^{\circ} \mathrm{C}$. To this solution $0.01 \mathrm{~mol}$ of trimethylamine was added and the whole contents were refluxed with stirring for $8 \mathrm{hrs}$. It was advised to take 
trimethylamine little excess. The obtained crude material was filtered on hot to remove the inorganic salt. The product was recrystallized from a mixture of acetone and methanol twice and was dried in vacuum and stored in cool, dry desiccator. The overall yield was 95\%.

\subsection{Synthesis of sodium salt of $\mathrm{N}$-(2-(carboxylatomethoxy)-3-(hexadecyloxypropyl)dimethyl glycinate (4)}

2-((3-carboxyacryloxy)oxy)3-(hexadecyloxy)-1-propyl chloride (2) $(0.01 \mathrm{~mol})$ was added to 0.01 mol of dimethylamine $33 \%, 1 \mathrm{~g}$ of $\mathrm{NaOH}$ and $5 \mathrm{ml}$ of distillated water using anhydrous ethanol as solvent. The reaction mixture was stirred for $4 \mathrm{hrs}$ at $75^{\circ} \mathrm{C}$ in the water bath. Then $0.12 \mathrm{~mol}$ of sodium chloroacetate were added drop wise to the reaction mixture and was stirred for 6-8 hrs at $75^{\circ} \mathrm{C}$ in water bath. The crude product was recrystallized with mixed ethanol and ethyl acetate then it was dried. The yield percent of the product was $97 \%$.

\subsection{Synthesis of poly (AAc/AAm/surfactant (3))}

Different weights of surfactants (3) $(0.01,0.02,0.03,0.04,0.05,0.0005 \mathrm{~g})$ were added to mixture of $60 \mathrm{ml}$ of acrylamide (AAm) which equal $42.6 \mathrm{~g}, 60 \mathrm{ml}$ of acrylic acid (AAc) and $80 \mathrm{ml}$ of distillated water, each mixture was stirred for two hrs, then the resulted mixtures were polymerized by using Gamma irradiation at $25 \mathrm{KGy}$ [27-29].

\subsection{Synthesis of poly (AAc/AAm/surfactant (4))}

Repeat the previous procedure at different weights of surfactant (4) $(0.01,0.02,0.03,0.04,0.05$, $0.00141 \mathrm{~g})$ [27-29].

\subsection{Metal uptake studies}

The adsorption of nickel ion in presence of polymer was performed by introducing constant weight $(0.1 \mathrm{~g})$ of polymer-surfactant in a flask containing $10 \mathrm{~mL}$ of a $900 \mathrm{ppm}$ solution of nickel ions. The mixture was stirred by a magnetic stirrer at room temperature and filtered. The residual nickel concentration was determined by complexometric titration with EDTA. The amount of metal ion uptake was calculated from the difference between a blank experiment without polymer and the reading in the actual experiment [30]. 
The removal percentage $\%$ was calculated using the following equation:

Removal \% $=\frac{C_{0}-C}{C_{0}} \times 100$

Where $C_{0}$ is the initial concentrations of metal ion $\left(\mathrm{mg} \mathrm{L}^{-1}\right), C$ is the concentration of metal ion at equilibrium $\left(\mathrm{mg} \mathrm{L}^{-1}\right)$.

\subsubsection{Effect of time}

Contact time adsorption experiments were studied at room temperature at various time intervals (30-120 min) at constant concentration of nickel ion solution (900 ppm) and constant weight of polymer surfactant $(0.1 \mathrm{~g})$. The mixture was stirred at the different time intervals. Then, the concentration of residual nickel ion was determined by EDTA at the end of each time [27-29].

\subsubsection{Effect of nickel ion concentration}

The effect of nickel ion concentration $(1150,900,600$ and $300 \mathrm{ppm})$ on the percentage of metal uptake was studied. For each concentration, $0.1 \mathrm{~g}$ of polymer-surfactant was added and mixed at the optimum time. Then, the removal percentage of metal ion was calculated [27-29].

\subsubsection{Effect of temperature}

Adsorption test was carried out in a series of flasks in a thermostatic cell at three different temperatures 40,50 and $60^{\circ} \mathrm{C}$. Each flask was filled with $10 \mathrm{~mL}$ of nickel ion solution (900 ppm) and $0.1 \mathrm{~g}$ of polymer-surfactant following the above mentioned procedure [27-29].

\section{Results and Discussion}

The structures of purified surfactants (3) and (4) were confirmed by elemental analysis. The results of elemental analyses (carbon, hydrogen and nitrogen contents) with the molecular formula and melting points are presented in Table (1). The experimental results were in a good agreement with those calculated for the suggested formula. Also all prepared surfactants were showed as waxy materials. 
Table 1. Analytical and physical data of the prepared surfactants

\begin{tabular}{|c|c|c|c|c|c|}
\hline \multirow[t]{2}{*}{ Compound } & \multirow[t]{2}{*}{ M.Wt. } & \multirow[t]{2}{*}{ Color } & \multicolumn{3}{|c|}{$\begin{array}{l}\text { Elemental analysis found } \\
\text { (Calc.) }\end{array}$} \\
\hline & & & C \% & $\mathrm{H} \%$ & $\mathrm{~N} \%$ \\
\hline $\begin{array}{l}\text { Surfactant (3) } \\
\mathrm{C}_{2} \mathrm{H}_{50} \mathrm{NO}_{5}\end{array}$ & 498 & Yellow waxy & $\begin{array}{l}68.42 \\
(68.41)\end{array}$ & $\begin{array}{l}10.96 \\
(10.94)\end{array}$ & $\begin{array}{l}3.07 \\
(3.06)\end{array}$ \\
\hline $\begin{array}{l}\text { Surfactant (4) } \\
\mathrm{C}_{2} \mathrm{H}_{48} \mathrm{NO}_{6} \mathrm{Na}_{2}\end{array}$ & 532 & Brown waxy & $\begin{array}{l}59.52 \\
(59.51)\end{array}$ & $\begin{array}{l}9.52 \\
(9.51)\end{array}$ & $\begin{array}{l}2.77 \\
(2.75)\end{array}$ \\
\hline
\end{tabular}

\subsection{FT-IR spectra}

The FT-IR spectrum (Fig. 1) of 1-chloro-3-(hexadecyloxy)propane-2-OL (1) showed band at 3364 $\mathrm{cm}^{-1}$ indicating the presence of hydroxyl group $(\mathrm{OH})$. The absorption band at $2917 \mathrm{~cm}^{-1}, 2831 \mathrm{~cm}^{-}$ ${ }^{1}$ indicated the presence of $\mathrm{C}-\mathrm{H}$ stretching of methyl group for cetyl moiety while bands at 1392 $\mathrm{cm}^{-1}$ and $1463 \mathrm{~cm}^{-1}$ for $\mathrm{CH}$ of $\mathrm{CH}_{3}$ group as bending. The band at $730 \mathrm{~cm}^{-1}$ was refered to $\mathrm{C}-\mathrm{Cl}$. The FT-IR spectrum of 2-((3-carboxyacryloxy)oxy)3-(hexadecyloxy)-1-propyl chloride (2) showed the characteristic absorption bands at 3395 and $1729 \mathrm{~cm}^{-1}$ indicating the presence of hydroxyl group of acid for maleyl moiety and carbonyl group of acid moiety, respectively. $\mathrm{CH}$ stretching of $\mathrm{CH}_{2}$ and $\mathrm{CH}_{3}$ groups of cetyl moiety appeared at 2283 and $2922 \mathrm{~cm}^{-1}$. Also, the bands at $1204 \mathrm{~cm}^{-1}$ and $717 \mathrm{~cm}^{-1}$ confirmed the presence of $\mathrm{C}-\mathrm{O}$ ester and $\mathrm{C}-\mathrm{Cl}$, respectively. The band at $1644 \mathrm{~cm}^{-1}$ depicted the presence of $\mathrm{C}=\mathrm{O}$ group of ester. The FT-IR spectrum of purified compound (3) (Fig. 2) observed the absorption band at $3427 \mathrm{~cm}^{-1}$ for acid and quaternary ammonium salt and the band of $\mathrm{C}-\mathrm{Cl}$ at $717 \mathrm{~cm}^{-1}$ disappeared due to quaternarization. FT-IR spectrum of surfactant (4) showed absorption bands at 3427, 2925, 2739, 1729,1641, 1259 and $1120 \mathrm{~cm}^{-1}$ for tertiaryamine, $\mathrm{CH}$ symmetric of $\mathrm{CH}_{3}, \mathrm{CH}$ asymmetric, $\mathrm{CH}$ stretching of $\mathrm{CH}_{3}$, carboxyl group, $\mathrm{C}=\mathrm{C}, \mathrm{C}-\mathrm{N}$ and $\mathrm{C}-\mathrm{O}$ group, respectively. FT-IR spectrum of poly (AAc/AAm/Surfactant (3)) (Fig.3) showed absorption bands at 3432 and $1633 \mathrm{~cm}^{-1}$ indicating the presence of hydroxyl group of acid and amide group, respectively. FT-IR spectrum of poly (AAc/AAm/Surfactant (4)) (Fig.4) showed absorption bands at 3430, 1645, 1453 and $1166 \mathrm{~cm}^{-1}$ 
indicating the presence of hydroxyl group of acid, carbonyl of amide group, C-O of ether and C$\mathrm{N}$, respectively.

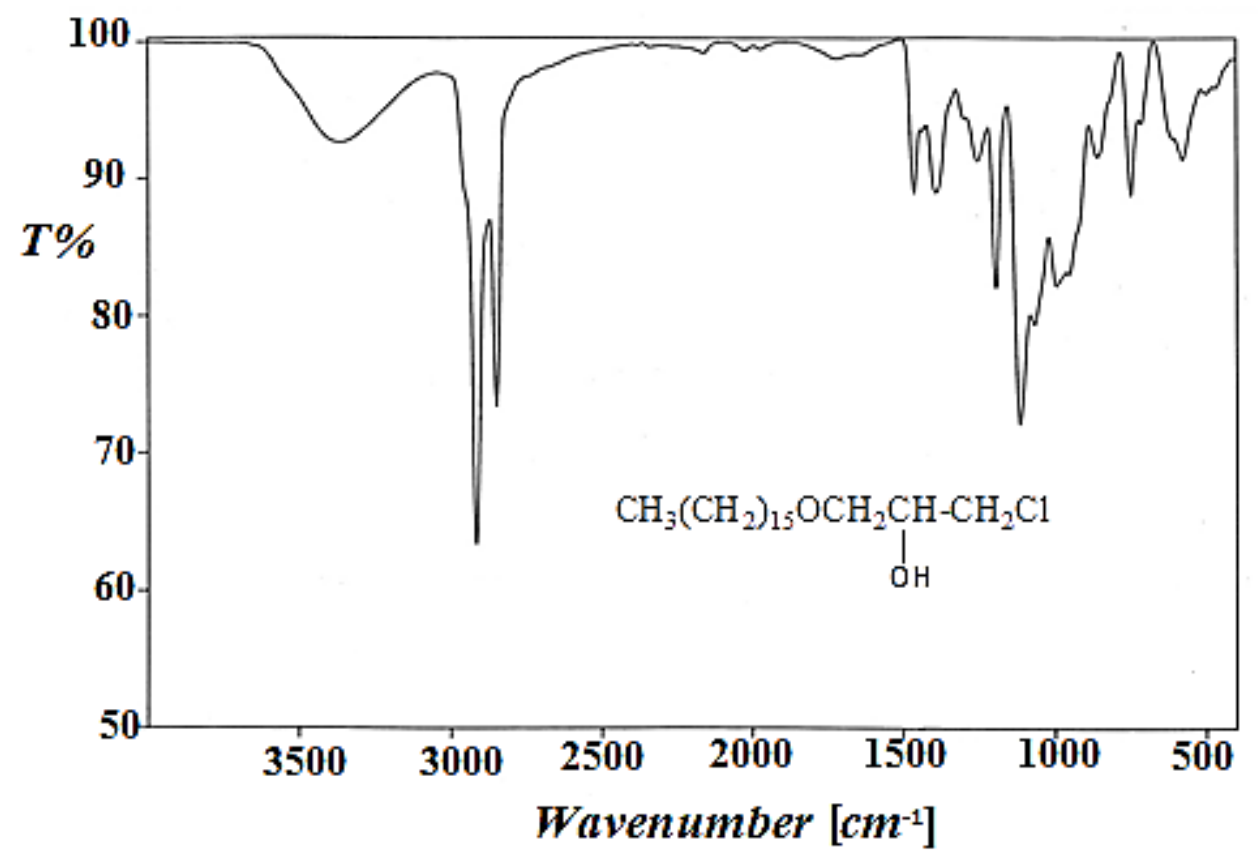

Fig.1. FT-IR spectrum of 1-chloro-3-(hexadecyloxy)propane-2-OL (1)

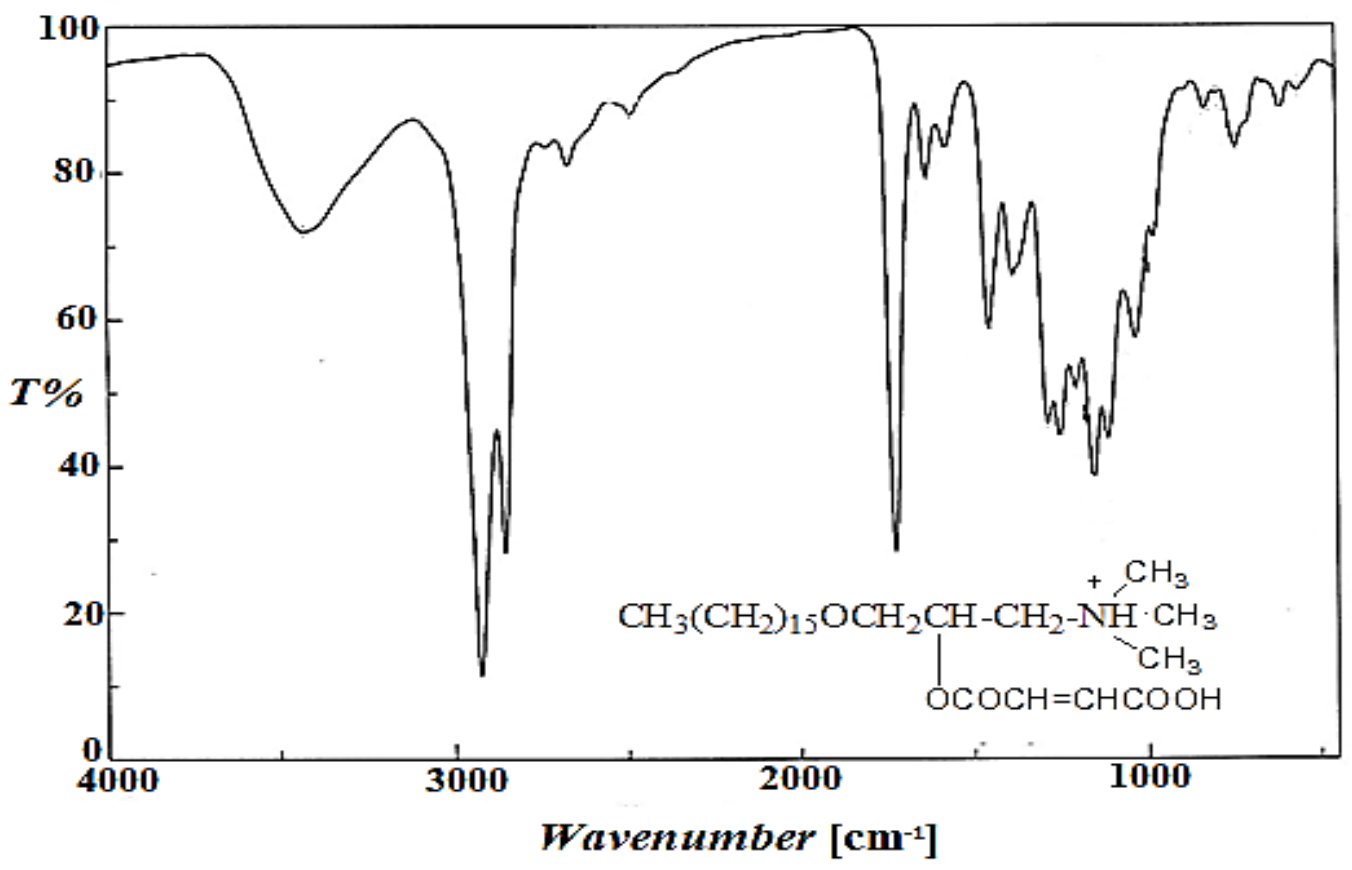


Fig.2. FT-IR spectrum of 2-((3-carboxyacryloxy)oxy)-3-(hexadecyloxy)-N,N,Ntrimethylpropane-1-ammonium chloride ( 3)

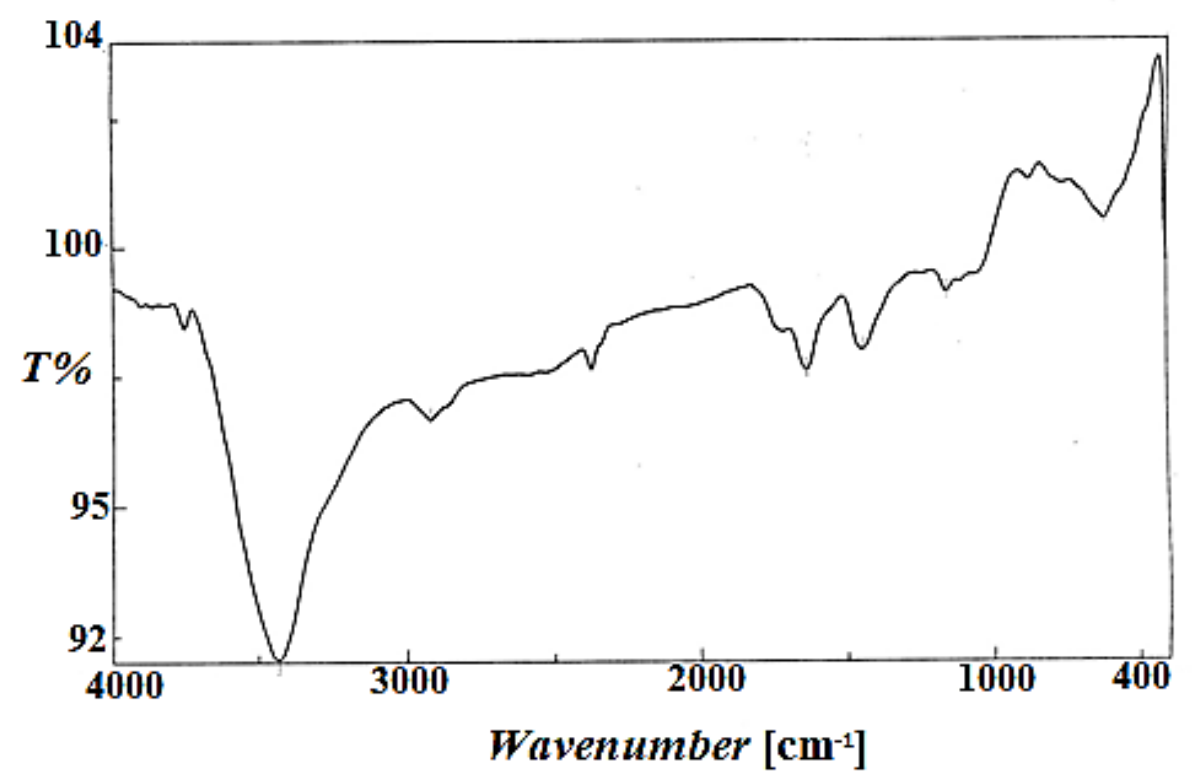

Fig.3. FT-IR spectrum of poly (AAc/AAm/surfactant (3))

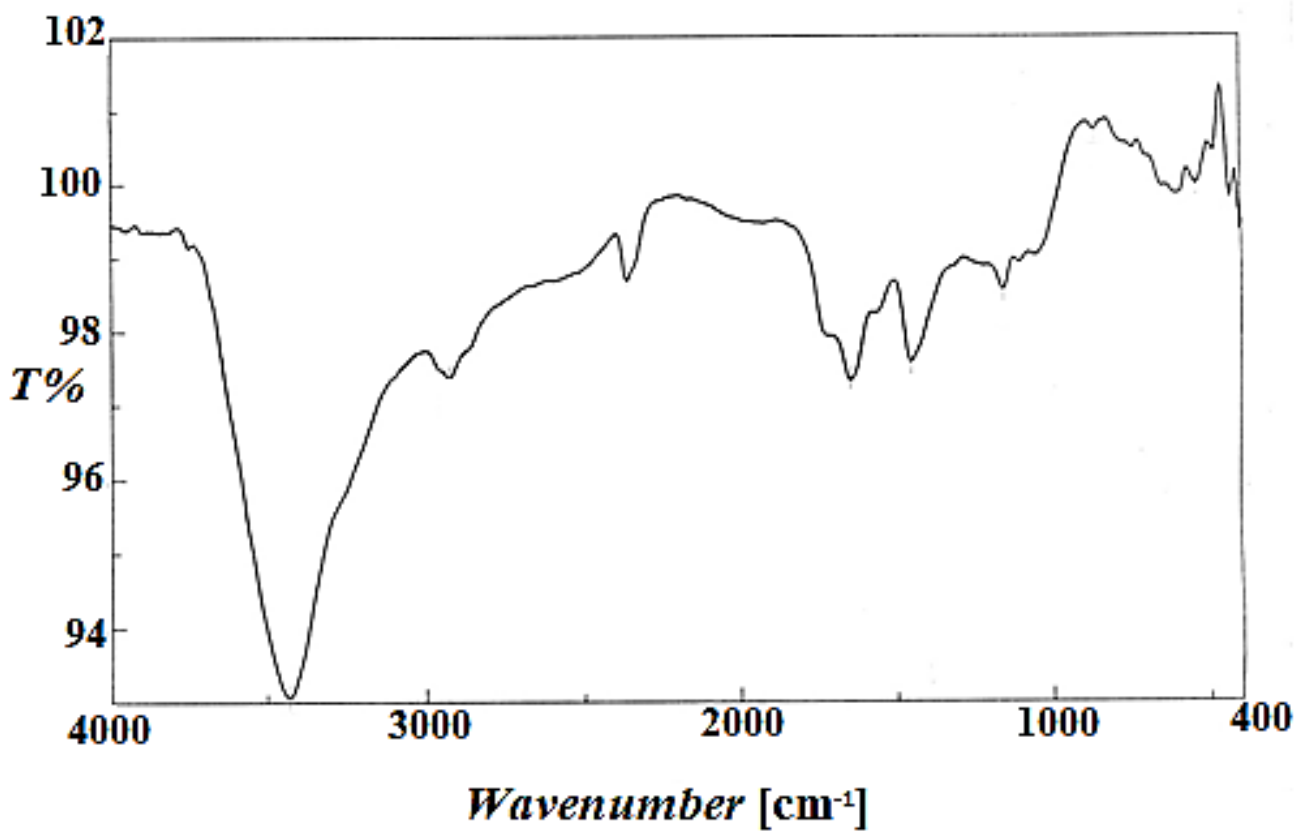

Fig.4. FT-IR spectrum of poly (AAc/AAm/surfactant (4)) 


\section{2. ${ }^{1} \mathrm{H}$ NMR spectra}

${ }^{1} \mathrm{H}$ NMR spectrum of compound (1) showed the chemical shift of $\delta 0.85-0.89\left(\mathrm{t}, 3 \mathrm{H}, \mathrm{CH}_{3}\right) ; \delta 1.25$ (m, 22H, $\left.\left(\mathrm{CH}_{2}\right)_{11}\right) ; \delta 1.53\left(\mathrm{~m}, 2 \mathrm{H},\left(\mathrm{CH}_{2}\right)_{11} \mathrm{CH}_{2}\right) ; \delta 1.54\left(\mathrm{~m}, 2 \mathrm{H},\left(\mathrm{CH}_{2}\right)_{2} \mathrm{CH}_{2}\right) ; \delta 1.56\left(\mathrm{~m}, 2 \mathrm{H},\left(\mathrm{CH}_{2}\right)_{13}\right.$ $\left.\mathrm{CH}_{2}\right) ; \delta 1.58\left(\mathrm{~m},\left(\mathrm{CH}_{2}\right)_{14} \mathrm{CH}_{2}\right) ; \delta 3.40-3.48\left(\mathrm{~m}, 2 \mathrm{H}, \mathrm{OCH}_{2}\right) ; \delta 3.51-3.80\left(\mathrm{~m}, 2 \mathrm{H}, \mathrm{CH}_{2} \mathrm{O}\right) ; \delta 3.93-$ $3.97\left(\mathrm{~m}, 1 \mathrm{H}, \mathrm{CH}-\mathrm{CH}_{2}\right) ; \delta 4.64\left(\mathrm{~m}, 2 \mathrm{H}, \mathrm{CHCH}_{2} \mathrm{Cl}\right)$ and $\delta 7.26(\mathrm{~s}, 1 \mathrm{H}, \mathrm{OH})$.

${ }^{1} \mathrm{H}$ NMR spectrum of 2-((3-carboxyacryloxy)oxy)3-(hexadecyloxy)-1-propyl chloride (2) showed $\delta$ 0.85-0.88 (t, 3H, $\left.\mathrm{CH}_{3}\right) ; \delta 1.25\left(\mathrm{~m}, 22 \mathrm{H},\left(\mathrm{CH}_{2}\right)_{11}\right) ; \delta 1.54\left(\mathrm{~m}, 24 \mathrm{H},\left(\mathrm{CH}_{2}\right)_{11} \mathrm{CH}_{2}\right) ; \delta 1.56(\mathrm{~m}, 26 \mathrm{H}$, $\left.\left(\mathrm{CH}_{2}\right)_{12} \mathrm{CH}_{2}\right) ; \delta 1.58\left(\mathrm{~m}, 28 \mathrm{H},\left(\mathrm{CH}_{2}\right)_{13} \mathrm{CH}_{2}\right) ; \delta 3.45\left(\mathrm{~m}, 2 \mathrm{H}, \mathrm{OCH}_{2}\right) ; \delta 3.75-3.62\left(\mathrm{~m}, 2 \mathrm{H}, \mathrm{CH}_{2} \mathrm{O}\right)$; $\delta 3.64-3.76(\mathrm{~m}, 1 \mathrm{H}, \mathrm{CH}) ; \delta 3.95-3.98\left(\mathrm{~m}, 2 \mathrm{H}, \mathrm{CH}_{2} \mathrm{Cl}\right) ; \delta 6.83(\mathrm{~s}, 1 \mathrm{H}, \mathrm{CH}=\mathrm{CH})$ and $\delta 7.26(\mathrm{~s}, 1 \mathrm{H}$, $\mathrm{OH}$ of acid).

${ }^{1} \mathrm{H}$ NMR spectrum of compound (3) in $\mathrm{CDCl}_{3}$ (Fig. 5(a, b)) showed a chemical signals at $\delta 0.78$ (t, $\left.3 \mathrm{H}, \mathrm{CH}_{3}\right) ; \delta 1.18\left(\mathrm{~m}, 26 \mathrm{H},\left(\mathrm{CH}_{2}\right)_{13}\right) ; \delta 1.41\left(\mathrm{~m}, 2 \mathrm{H},\left(\mathrm{CH}_{2}\right)_{13}-\mathrm{CH}_{2}\right) ; \delta 1.52\left(\mathrm{~m}, 2 \mathrm{H},\left(\mathrm{CH}_{2}\right)_{14} \mathrm{CH}_{2}\right)$; $\delta 3.4\left(\mathrm{~s}, 2 \mathrm{H}, \mathrm{CH}_{2} \mathrm{OCH}_{2}\right) ; \delta 3.73$ (t, 2H, CH-OCH 2$) ; \delta 3.29\left(\mathrm{~s}, 9 \mathrm{H}, \mathrm{N}\left(\mathrm{CH}_{3}\right)_{3}\right) ; \delta 3.52$ (d, 2H, $\left.\mathrm{CH}_{-} \mathrm{CH}_{2}\right)$; $\delta 5.4(\mathrm{~s}, \mathrm{H}, \mathrm{CH}) ; \delta 6.37(\mathrm{~d}, 1 \mathrm{H}, \mathrm{CH}=\mathrm{CH})$ and $\delta 6.50(\mathrm{~d}, 1 \mathrm{H}, \mathrm{CH}=\mathrm{CH})$.

${ }^{1} \mathrm{H}$ NMR spectrum of surfactant(4) (Fig.7) showed chemical signals at $80.75-0.79\left(\mathrm{t}, 3 \mathrm{H}, \mathrm{CH}_{3}\right)$; $\delta 1,08\left(\mathrm{~m}, 24 \mathrm{H},\left(\mathrm{CH}_{2}\right) 12\right) ; \delta 1.12\left(\mathrm{~m}, 2 \mathrm{H},\left(\mathrm{CH}_{2}\right)_{12} \mathrm{CH} 2\right) ; \delta 1.14\left(\mathrm{~m}, 2 \mathrm{H},\left(\mathrm{CH}_{2}\right)_{13}-\mathrm{CH} 2\right) ; \delta 1.16(\mathrm{~m}$, $\left.2 \mathrm{H},\left(\mathrm{CH}_{2}\right)_{14} \mathrm{CH}_{2}\right) ; \delta 3.40\left(\mathrm{~s}, 2 \mathrm{H}, \mathrm{CH}_{2} \mathrm{O}\right) ; \delta 3.84\left(\mathrm{~s}, 2 \mathrm{H}, \mathrm{OCH}_{2}\right) ; \delta 3.45\left(\mathrm{~d}, 1 \mathrm{H}, \mathrm{OCH}_{2}-\mathrm{CH}\right) ; \delta 2.60(\mathrm{~s}$, $\left.2 \mathrm{H}, \mathrm{CH}_{2} \mathrm{~N}\right) ; \delta 2.85\left(\mathrm{~s}, 6 \mathrm{H}, \mathrm{N}\left(\mathrm{CH}_{3}\right)_{2}\right) ; \delta 3.39\left(\mathrm{~s}, 2 \mathrm{H}, \mathrm{NCH}_{2} \mathrm{COO}\right) ; \delta 4.07(\mathrm{~s}, 1 \mathrm{H}, \mathrm{CH}) ; \delta 4.08(\mathrm{~d}, 1 \mathrm{H}$, $\mathrm{CH}=\mathrm{CH})$ and $\delta 5.9(\mathrm{~s}, 1 \mathrm{H}, \mathrm{CH}=\mathrm{CH})$. 


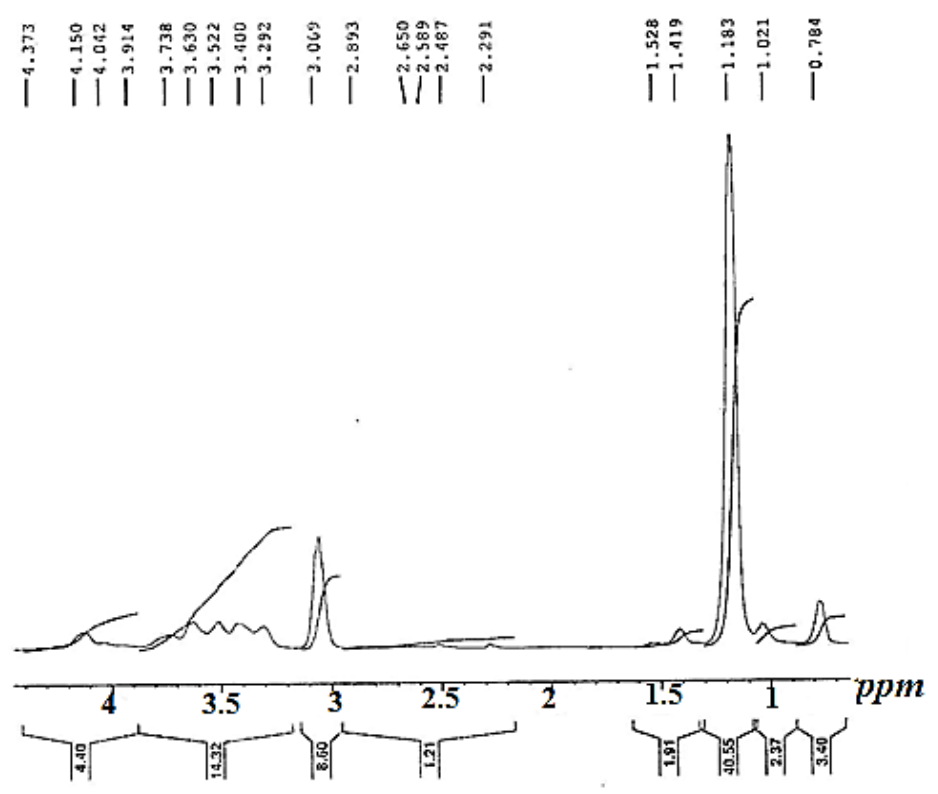

Fig.5.a ${ }^{1} \mathrm{H}$ NMR spectrum of 2-((3-carboxyacryloxy)oxy)-3-(hexadecyloxy)-N,N,N-trimethyl propane-1-ammonium chloride (3)

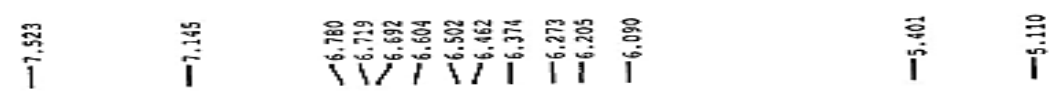

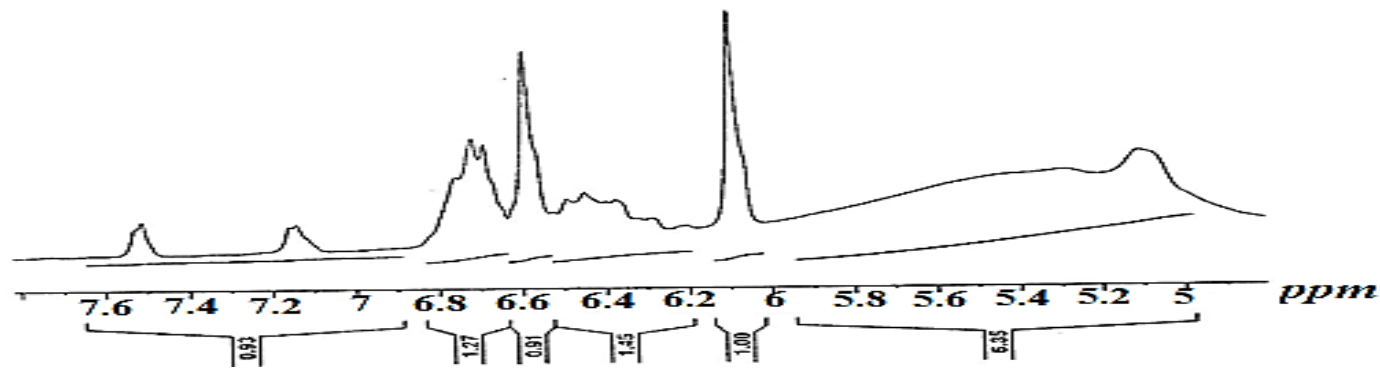

Fig.5.b ${ }^{1} \mathrm{H}$ NMR spectrum of 2-((3-carboxyacryloxy)oxy)-3-(hexadecyloxy)-N,N,N-trimethyl propane-1-ammonium chloride (3) 


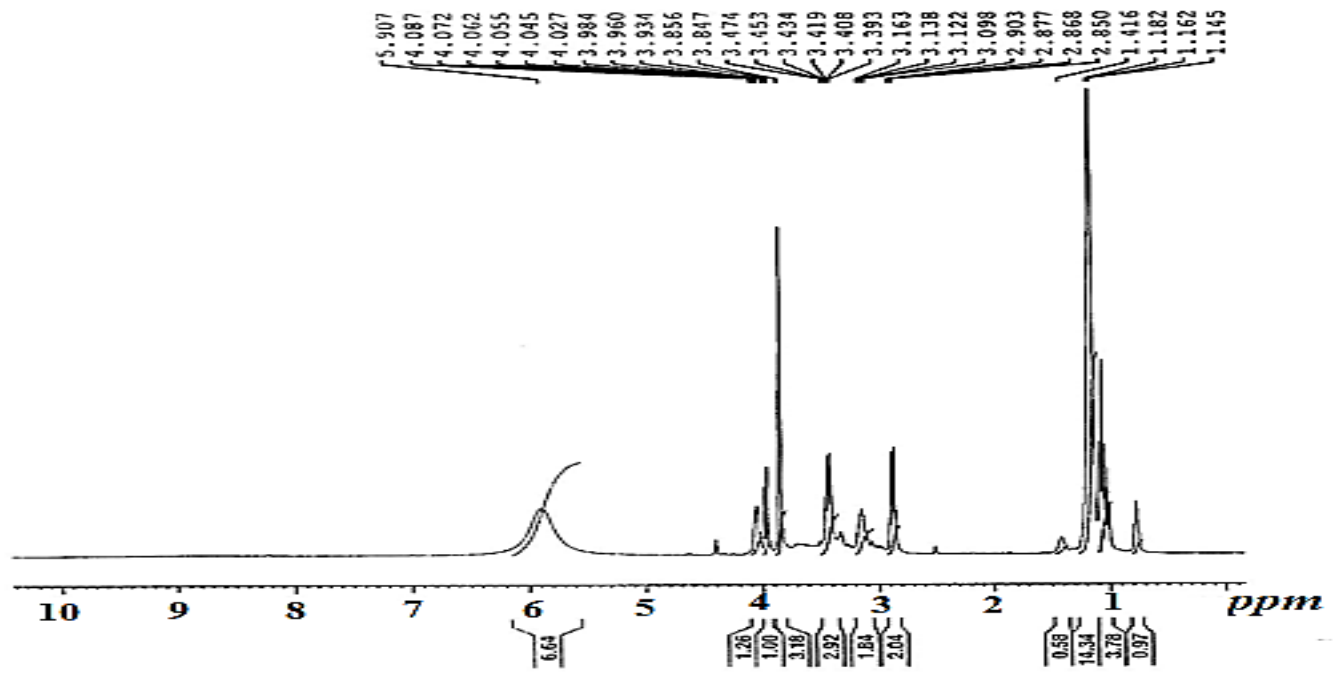

Fig.6. ${ }^{1} \mathrm{H} \quad$ NMR $\quad$ spectrum of $\quad \mathrm{N}$-(2-(carboxylatomethoxy)-3-(hexadecyloxypropyl)dimethyl glycinate (4)

\subsection{Surface tension measurements}

Surface tension (ST) measurements were performed with freshly prepared solutions of surfactants in a concentration range from $10^{-1}$ to $10^{-6} \mathrm{~mol} \mathrm{~L}^{-1}$ at $25^{\circ} \mathrm{C}$ using a Du-Nouy tensiometer. These values, which were remained to be constant for a period over 30 minutes are taken as the surface tension of the solution. The results were accurate within $\pm 0.1 \mathrm{mn} \mathrm{m}^{-1}$. The relation between surface tension (8) versus $\log$ arithm of concentration $(-\log C)$ for the prepared surfactants aqueous solution was obtained at $25^{\circ} \mathrm{C}$ as shown in Fig. (7). The critical micelle concentration (cmc) and surface tensions were determined as the values of the break point of surface tension versus logarithm concentration plots. From figure (7), the cmc of both surfactants (3) and (4) were found to be 0.0005 and $0.00141 \mathrm{mN} \mathrm{m}^{-1}$, respectively [31]. 

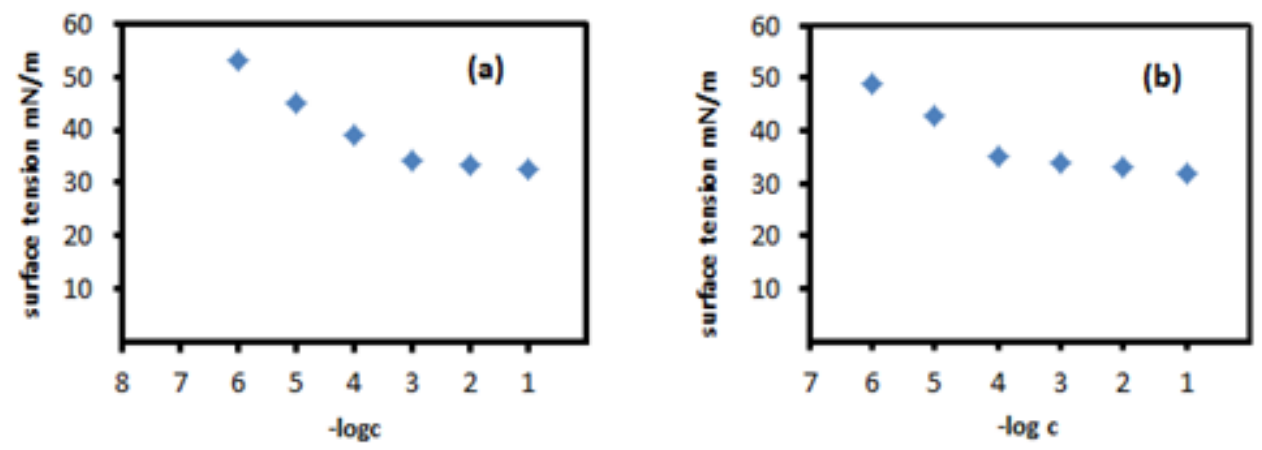

Fig.7. Surface tension of surfactant (3) (a) and surfactant (4) (b)

\subsection{Effect of contact time on swelling percentage of poly (AAc/AAm/surfactant (3))}

The effect of the time on the swelling ratio for poly (AAc/AAm/surfactant (3)) at different weight of surfactant (3) $(0.01,0.02,0.03,0.04,0.05,0.005 \mathrm{~g})$ in distillated water was shown in Fig. (8).The figure showed that the swelling percent of the hydrogels increased with increasing the contact time up to $24 \mathrm{hrs}$ and then leaves off. The highest swelling percent was $1790 \%$ at surfactant weight $=0.04 \mathrm{~g}$ compared with $300 \%$ for swelling percentage of poly acrylic acid/poly vinyl alcohol and $150 \%$ for swelling percentage of poly acrylic acid [29]. 


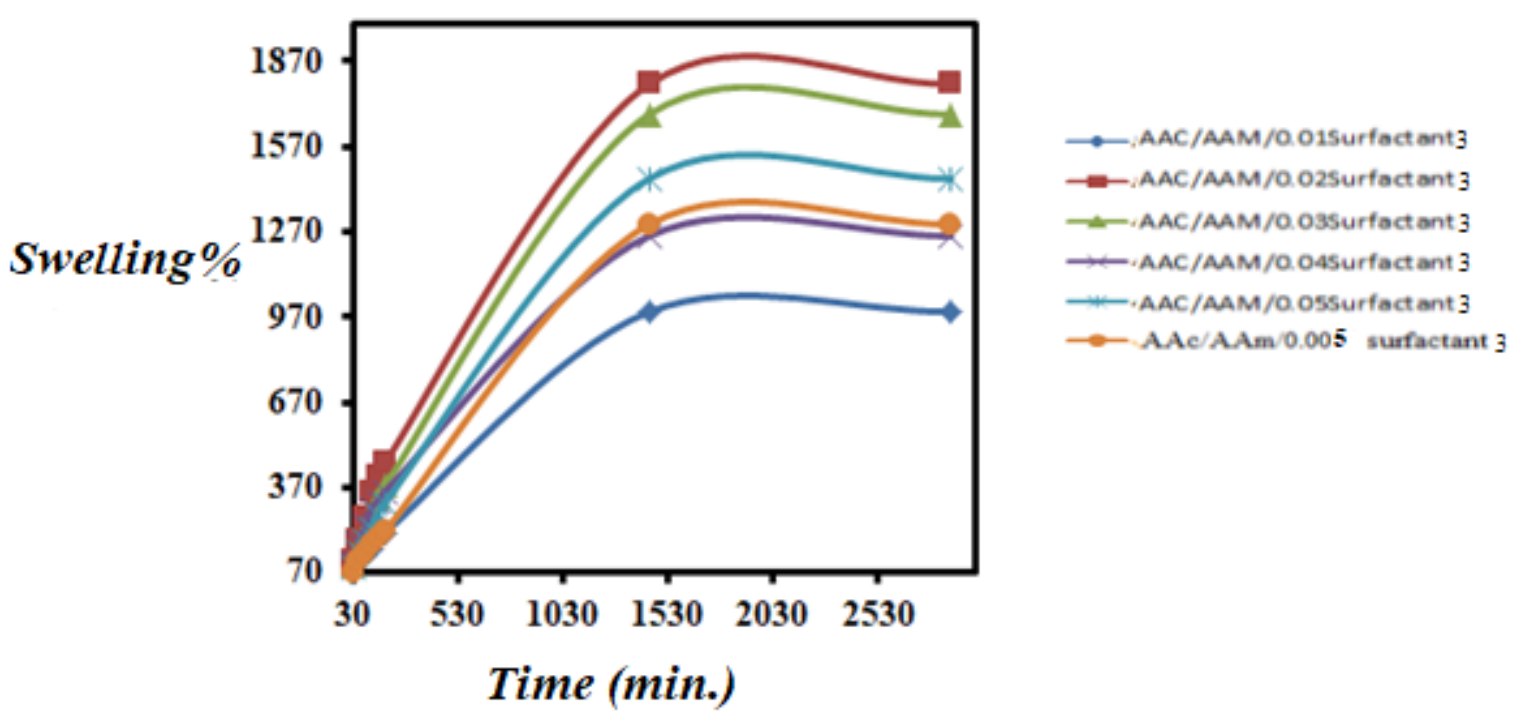

Fig.8. Effect of time on the swelling \% of poly (AAc/AAm/surfactant (3)) at $25 \mathrm{KGy}$

\subsection{Effect of contact time on swelling percentage of poly (AAc/AAm/surfactant (4))}

The effect of the time on the swelling ratio for poly (AAc/AAm/surfactant (4)) at different weight of surfactant (4) $(0.01,0.02,0.03,0.04,0.05,0.00141 \mathrm{~g})$ in distillated water is shown in Fig.9. The figure showed that the swelling percent of the hydrogels increased with increasing the contact time up to $24 \mathrm{hrs}$ and then leaves off. The highest swelling percent was $1492 \%$ at surfactant weight $=0.02 \mathrm{~g}$ compared with $300 \%$ for swelling percentage of poly acrylic acid/poly vinyl alcohol and $150 \%$ for swelling percentage of poly acrylic acid [29]. 


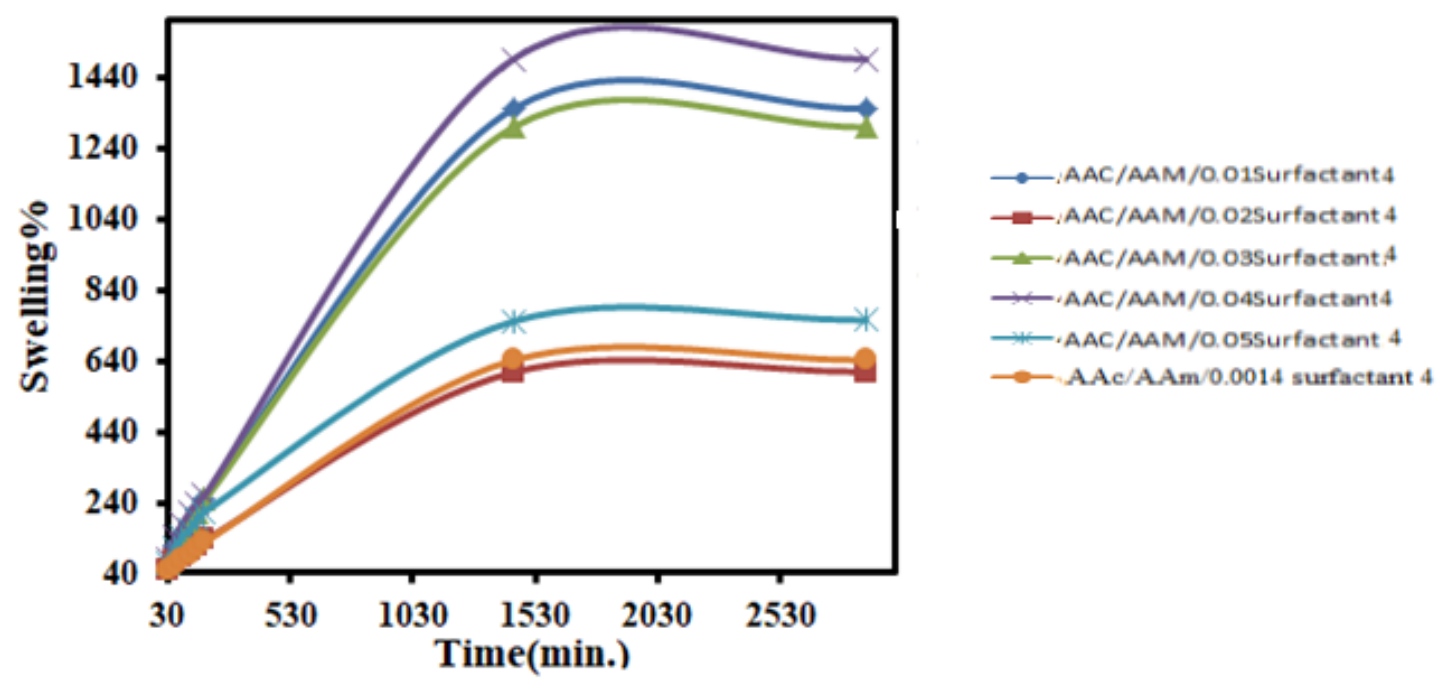

Fig.9. Effect of contact time on swelling \% of poly (AAc/AAm/surfactant (4)) at 25KGy

\subsection{Application}

\subsubsection{Metal uptake study}

The effect of the contact time on removal percentage of nickel ion by poly (AAc/AAm/surfactant (3)) and poly (AAc/AAm/surfactant (4)) shown in Fig.10 (a, b). The results showed that the removal percentage increased with the contact time till reach to optimum removal $40 \%$ after $3 \mathrm{hrs}$ by poly (AAc/AAm/surfactant (3)) and $35 \%$ after 2 hrs by poly (AAc/AAm/surfactant (4)) [2729]. 

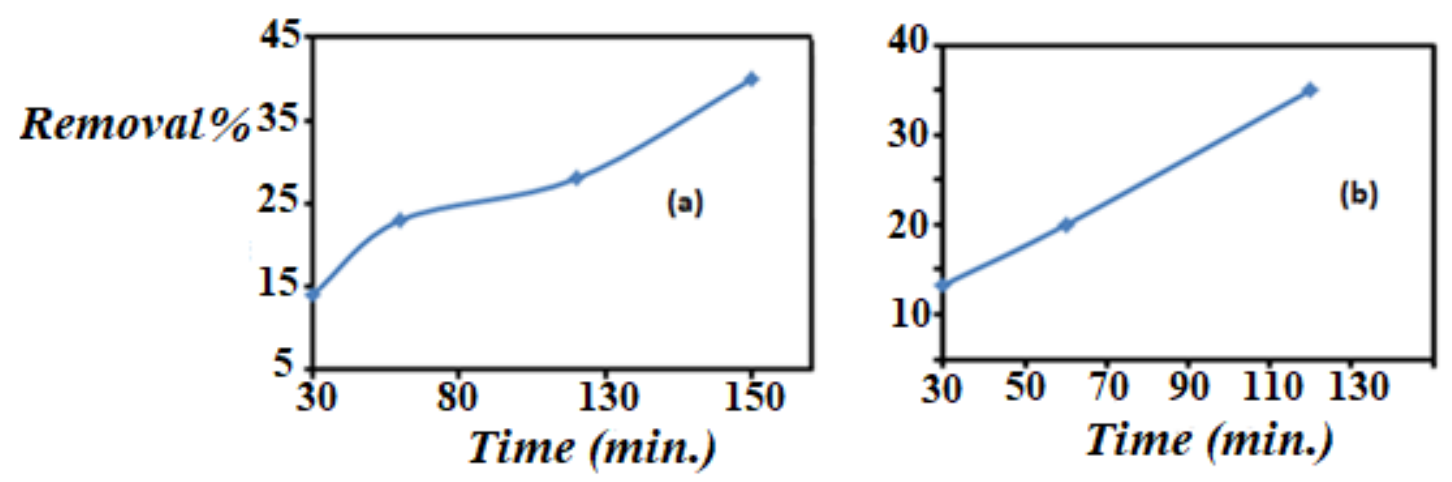

Fig.10. Effect of time on removal percentage of nickel ion of poly (AAc/AAm/Surfactant (3)) (a) and poly (AAc/AAm/surfactant (4)) (b).

The relation between the initial nickel ion concentration and removal percentage was determined by poly (AAc/AAm/Surfactant (3)) and poly (AAc/AAm/Surfactant (4)) (Fig.11 (a, b)) at the optimum time 2 and $3 \mathrm{hrs}$, respectively. The results showed that the removal percentage increased as concentration of nickel ion solution decrease till reach to optimum removal $78 \%$ at $300 \mathrm{ppm}$ of nickel ion by poly (AAc/AAm/Surfactant (3)) and $67 \%$ at $300 \mathrm{ppm}$ of nickel ion by poly (AAc/AAm/Surfactant (4)) [27-29].
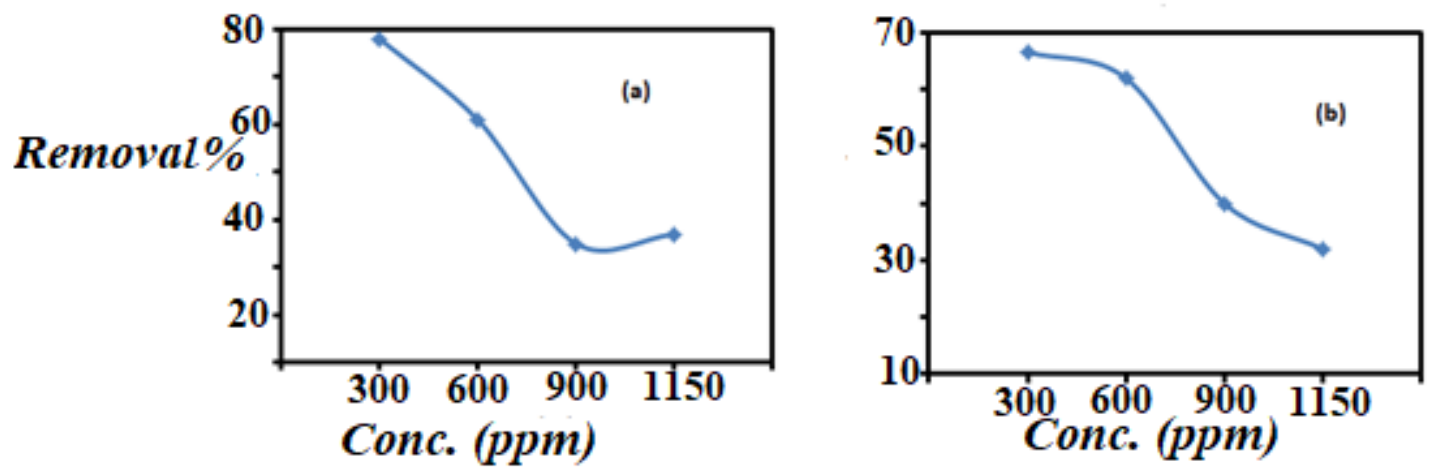

Fig.11. Effect of initial concentration of nickel ion solution on removal percentage by poly (AAc/AAm/Surfactant (3)) (a) and poly (AAc/AAm/Surfactant (4)) (b) 
The effect of temperature on removal percentage was studied by poly (AAc/AAm/Surfactant (3)) at the optimum time $2 \mathrm{hrs}$ and poly (AAc/AAm/Surfactant (4)) at the optimum time $3 \mathrm{hrs}$ (Fig.12 $(a, b))$. The results showed that the removal percentage increased with temperature. The optimum removal percentage at $60^{\circ} \mathrm{C}$ was reached at $67 \%$ by poly (AAc/AAm/Surfactant (3)) and $73 \%$ by poly (AAc/AAm/Surfactant (4)) [27-29].
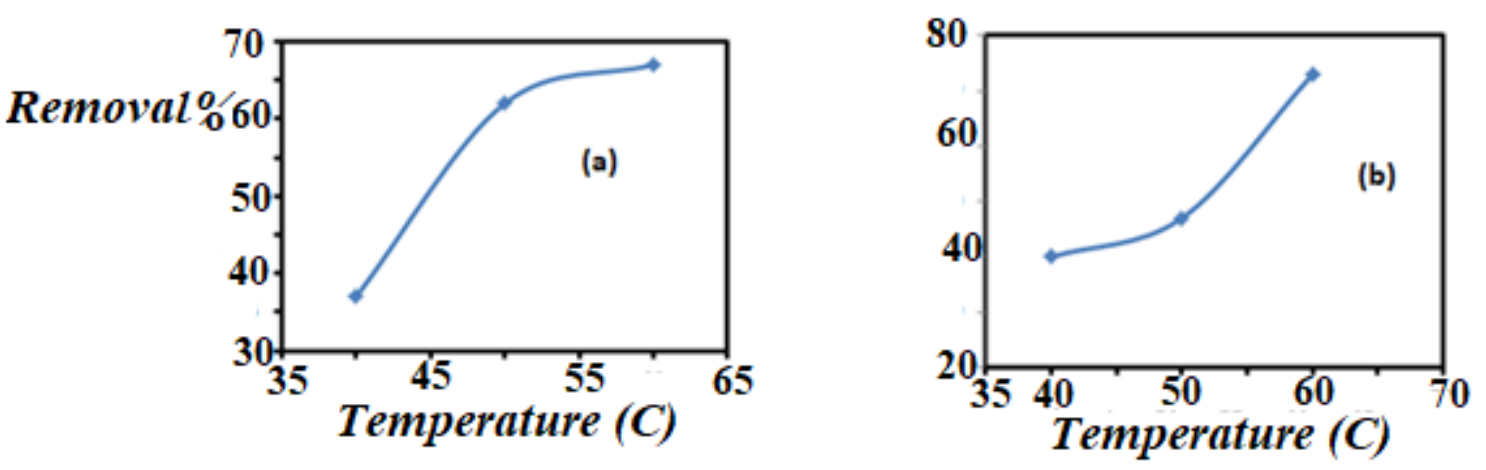

Fig.15. Effect of temperature on removal percentage of nickel ion by poly (AAc/AAm/Surfactant (3)) (a) and poly (AAc/AAm/Surfactant (4)) (b)

\section{Conclusion}

In this study gamma irradiation was used for the synthesis of poly acrylic acid /acrylamide with two amphoteric surfactants for the purpose of removal of heavy metal from waste water. The functional groups and crosslinking chemical structure of the amphoteric surfactants and polymer surfactant are confirmed by Fourier transform infrared spectrometry (FTIR) and ${ }^{1} \mathrm{H}$ NMR spectra. The kinetic swelling behavior was determined. The prepared hydrogels were examined for $\mathrm{Ni}^{+2}$ removals from aqueous solution. The factors affecting the removal percentage such as contact time, initial metal ion concentration and temperature were studied. 


\section{References}

[1] Z. Zhang, T. Gao, S. Si, Q. Liu, Y. Wu, G. Zhou "One-pot preparation of P(TA-TEPA)PAM-RGO ternary composite for high efficient $\mathrm{Cr}(\mathrm{VI})$ removal from aqueous solution", Chem. Eng. J. 343: (2018) 207-216.

[2] V. Manirethan, K. Raval, R. Rajan, H. Thaira, R. Balakrishnan "Green synthesis of tanninhexamethylendiamine based adsorbents for efficient removal of $\mathrm{Cr}(\mathrm{VI})$ ”, J. Hazard.

Mater., 352: (2018) 27-35

[3] H. Zhang, P. Li, Z. Wang, Wen. Cui, Y. Zhang, Y. Zhang, S. Zheng, Y. Zhang "Sustainable disposal of $\mathrm{Cr}(\mathrm{VI})$ : adsorption-reduction strategy for treating textile wastewaters with aminofunctionalized boehmite hazardous solid wastes ACS Sustain”. Chem. Eng., 6: (2018) 68116819.

[4] A. Jacquesa, J. Montelongo, C. Cuevasb, M. Valadez, M. Estevez, A. Martínez “Lead (II) removal by poly(N,N-dimethylacrylamide-co-2-hydroxyethyl methacrylate)" Eur. Polym. J., 101: (2018) 262-272

[5] A. Zhou, W. Chen, L. Liao, P. Xie, T. Zhang, X. Wu, X. Feng "Comparative adsorption of emerging contaminants in water by functional designed magnetic poly $(\mathrm{N}$ isopropylacrylamide)/chitosan hydrogels" Sci. Total Environ., 671: (2019) 377-387

[6] A. Barati, M. Asgari, T. Miri, Z. Eskandari, "Removal and recovery of copper and nickel ions from aqueous solution by poly(methacrylamide-co-acrylic acid)/montmorillonite Nano composites", Environ. Sci.Pollut. Res.20: (2013) 6242-6255, doi 10.1007/s11356-013-1672-3.

[7] M. Mohammadian, R. Sahraei, M. Ghaemy "Synthesis and fabrication of antibacterial hydrogel beads based on modified-gum tragacanth/poly(vinyl alcohol)/ $\mathrm{Ag}^{0}$ highly efficient sorbent for hard water softening" Chemosphere, 225: (2019) 259-269

[8] J. He, A. Cui, F. Ni, S. Deng, F. Shen, G. Yang "A novel 3D yttrium based-graphene oxidesodium alginate hydrogel for remarkable adsorption of fluoride from water", J. Colloid Interf. Sci., 531 (2018) 37-46

[9] T. Hong, H. Okabe, Y. Hidaka, K. Hara "Removal of metal ions from aqueous solutions using carboxymethyl cellulose/sodium styrene sulfonate gels prepared by radiation grafting", Carbohyd. Polym., 157 (2017), pp. 335-343

[10] J. Ma, J. Luo, Y. Liu, Y. Wei, T. Cai, X. Yu, H. Liu, C. Liu, J. Crittenden 'Pb(II), Cu(II) and $\mathrm{Cd}(\mathrm{II})$ removal using a humic substance-based double network hydrogel in individual and multicomponent systems"

J. Mater. Chem. A, 6 (2018) 20110-20120.

[11] X. Wang, Y. Liang, W. An, J. Hu, Y. Zhu, W. Cui "Removal of chromium (VI) by a selfregenerating and metal free $\mathrm{g}-\mathrm{C}_{3} \mathrm{~N}_{4} /$ graphene hydrogel system via the synergy of adsorption and photo-catalysis under visible light", Appl. Catal. B Environ., 219 (2017) 53-62 
[12] G. Q. Zhao, C. C. Khin, S. B. Chen, B. H. Chen, "Nonionic surfactant and temperature effects on the viscosity of hydrophobically modified hydroxyethyl cellulose solutions", J. Phys. Chem. 109: (2005) $14198-14204$.

[13]S. Kashyap, M. Jayakannan, "Amphiphilic Diblocks Sorting into Multi vesicular Bodies and Their Fluorophore Encapsulation Capabilities”, J. Phys. Chem. 116: (2012) 9820-9831.

[14] A. C. John, H. Uchiyama, K. Nakamura, H. Kunieda, "Phase behavior of a water/ nonionic surfactant/oil ternary system in the presence of polymer oil”, J. Colloid Interface Sci. 186: (1997) $294-299$.

[15] W.Wang, Z. P. Guo, Y. Chen, T. Liu, L. Jiang, "Influence of generation 2-5 of PAMAM dendrimer on the inhibition of Tat peptide/TAR RNA binding in HIV-1 transcription", Chem. Biol. Drug. Design.68: (2006) 314-318.

[16] H.Yarveicy, A. Haghtalab, "Effect of amphoteric surfactant on phase behavior of hydrocarbon-electrolyte-water system-an application in enhanced oil recovery", J. of Dispersion Sc. and Technology, 39: (2018) 522-530.

[17]X. Chen, Y. Xin, F. Yu, Z. Lan, "Micellization and Adsorption Properties of Novel Zwitterion Surfactants" J.Surfact.Deter.20: (2017) 1121-1127.

[18]X.Wang, X.Shang, P.Liu and F.Xie, "Kinetic Modeling of Palmitamidopropyl Betaine Synthesis", J.Surfact.Deterg.21: (2018) 647-655, https://doi.org/10.1002/jsde.12156.

[19] E.Palunch, A. Piecuch, E.Oblak, E.Lamch and K.A.Wilk, "Antifungal activity of newly synthesized chemodegradable dicephalic-type cationic surfactants", Colloids and Surface B.Biointerface 164: (2018) 34-41.

[20] S.Jian, Y.Hing and Y.bosong, "Characterization and Performance of Unsaturated Long-Chain Carboxybetaine and Hydroxy Sulfobetaine”, J.surfactant.Deterg.16: (2013) 523-529, doi 10.1007/s11743-013-1441-9.

[21] Y.Sun, J.A. Kaplan, A. Shieh, H. L.Sun, C.M.Croce, M.W. Grinstaff, J.R. Parquette, "Selfassembly of a 5-fluorouracil-dipeptide hydrogel", Chem. Commun. 52: (2016) 5254-5257, doi: 10.1039/c6cc01195k.

[22] S.H. Kim, Y.Sun, J.A. Kaplan, M.W. Grinstaff, J.R. Parquette, "Photo-crosslinking of a selfassembled coumarin-dipeptide hydrogel", New J. Chem. 39: (2015) 3225-3228.

[23]S. K. Bajpai, "Swelling Studies on Hydrogel Networks-A Review”, J. of Sci.and Industrial Res.60: (2001) 451-462.

[24] N.C. Dafader, T. Akter, M. E. Haque, S. P. Swapna, S. Islam and D. Huq, "Effect of acrylic acid on the properties of polyvinylpyrrolidone hydrogel prepared by the application of gamma radiation", African J. of Biotech. 11: (2012) 13049-13057. 
[25] L.V., Qingyun, H.U., Xiaosai, X., Zhang, L., Huang, Z., Liu,G, Sun, "Highly efficient removal of trace metai ions using poly(acrylic acid) hydrogel adsorbent", J. Materials and Design 181:(2019) 107934-107945

[26] Ab. M., Zaidan, M., Asadi, International J. of Eng. and Techn 3: (2015)141-145

[27] E., Manaila, G., Craciun, D., Ighigeanu, C., Cimpeanu, C., Barna, and V., Fugaru, "Hydrogels Synthesized by Electron Beam Irradiation for Heavy Metal Adsorption”, J. of Materials 10: (2017) 540-562.

[28] J.L Morán-Quiroz, E., Orozco-Guareño, R., Manríquez, G.G., Carbajal-Arízaga, W., Cruz, S., Gomez-Salazar, "Polymeric hydrogels obtained using a redox initiator: Application in $\mathrm{Cu}(\mathrm{II})$ ions removal from aqueous solutions", J. of App. Poly. SC. 131: (2014) 39933-39944.

[29] N.A., Maziad, M., Mohsen, E., Gomaa, and R., Mohammed, "Characterization of Some Hydrogels Used in Water Purification: Correlation of Swelling and Free-Volume properities", J. of Materials Science and Engineering 5: (2015) 381-390.

[26] Ab. M., Zaidan, M., Asadi, International J. of Eng. and Techn 3: (2015)141-145

[30] J., Zhai and E., Bakker, "Complexometric titrations: new reagents and concepts to overcome old limitations", J. of the Royal Society of Chemistry 141: (2016) 4252-4261.

[31] Findly; practical physical chemistry. $6^{\text {th }}$ ed., 101, p:92, (1963). 